\title{
Effect of Coffee Husk Compost and NPSB Fertilizers on Selected Soil Chemical Properties of Potato Field in Chora District, South West Ethiopia
}

\author{
Temam Jibril ${ }^{1}$ and Getachew Bekele $\mathbb{( i D}^{2}$ \\ ${ }^{1}$ Mettu University, College of Agriculture and Forestry, Department of Soil Sciences, Bedele, Ethiopia \\ ${ }^{2}$ Mettu University, Bedelle College of Agriculture and Forestry, Department of Plant Sciences, Bedelle, Ethiopia \\ Correspondence should be addressed to Getachew Bekele; getme.bekele@gmail.com
}

Received 2 October 2021; Accepted 4 January 2022; Published 8 February 2022

Academic Editor: Claudio Cocozza

Copyright (c) 2022 Temam Jibril and Getachew Bekele. This is an open access article distributed under the Creative Commons Attribution License, which permits unrestricted use, distribution, and reproduction in any medium, provided the original work is properly cited.

Field experiment was conducted in Chora District of south western Ethiopia, to evaluate the effect of different rates of coffee husk compost $(\mathrm{CHC})$ and $18.9 \mathrm{~N}+37.7 \mathrm{P}+6.94 \mathrm{~S}+0.15 \mathrm{~B}(\mathrm{NPSB})$ in the form of $\mathrm{NH}_{4}, \mathrm{P}_{2} \mathrm{O}_{5}, \mathrm{SO}_{4}^{-}$, and $\mathrm{B}_{2} \mathrm{O}_{5}$, repectively, blended fertilizer on selected soil chemical properties of potato field during 2021. The treatment consisted of four rates of CHC $(0,2.5,5$, and $\left.7.5 \mathrm{tha}^{-1}\right)$ and four rates of blended NPSB fertilizer $\left(0,112.5,150\right.$, and $\left.187.5 \mathrm{~kg} \mathrm{ha}^{-1}\right)$. The experiment was laid out in randomized complete block design with three replications. Postharvest soil data were collected and subjected to ANOVA using SAS version 9.4. All the soil parameters analyzed were significantly $(P<0.05)$ affected by the main factors of CHC and NPSB blended fertilizer except exchangeable $\mathrm{K}^{+}$and $\mathrm{Na}^{+}$which were affected by main factors but not by factors interaction. The maximum $\mathrm{pH}$ (5.3), OC (6.0\%), and CEC (14.10 meq $\left.100 \mathrm{~g}^{-1}\right)$ were obtained from application of sole 7.5.t CHC ha ${ }^{-1}$ which is at par with combined 7.5.t CHC and $112.5 \mathrm{~kg} \mathrm{NPSB} \mathrm{ha}^{-1}$, while the maximum TN (26\%), Av. P (3.57\%), and Av. S (4.36\%) were obtained from combined application of 7.5.t CHC and $112.5 \mathrm{~kg} \mathrm{NPSB} \mathrm{ha}^{-1}$. The sole application of either of $150 \mathrm{~kg}$ or $187.5 \mathrm{~kg} \mathrm{NPSB} \mathrm{ha}^{-1}$ was resulted in high exchangeable acidity. Therefore, combined application of CHC and NPSB fertilizers raised the $\mathrm{pH}$, improves the OC\%, total N, available P and S, reduced the exchangeable acidity, and raises the CEC and exchangeable bases of potato field soil as compared to the control and sole NPSB fertilizer.

\section{Introduction}

The Ethiopian economy heavily relies on agriculture [1] and the sector has contributed approximately $44 \%$ to the GDP of the country [2]. Soil resource degradation and nutrient depletion of agricultural soil are the major challenges in agricultural production in developing nations, such as Ethiopia and Chora District in particular [3]. Potato (Solanum tuberosum L.) is the world's most important tuber crop and is the fourth most important food crop in terms of human consumption and cultivation in the world next to wheat, maize, and rice $[1,4]$. Potato ranks first among root and tuber crops grown in Ethiopia in terms of area coverage, total production, and consumption followed by taro, sweet potato, and onion [5].
Ethiopia, particularly south western part, faces a wide set of soil fertility issues (poor in fertility; soil acidity; low soil $\mathrm{pH}$; significantly depleted organic matter; leaching of $\mathrm{N}, \mathrm{K}$, and micronutrients; and phosphorus (P) fixation) that require approaches that go beyond the application of chemical fertilizers [6, 7]. Beside this, inadequate application of organic and inorganic nutrient sources of fertilizers to replenish the nutrient depletion is challenge to crop production and productivity in Ethiopia including south western [8].

Ethiopian farmers are using mostly inorganic fertilizers like diammonium phosphate (DAP), urea and N, P, and $\mathrm{S}$ with the proportion of $19 \% \mathrm{~N}, 38 \% \mathrm{P}_{2} \mathrm{O}_{5}$, and $7 \% \mathrm{~S}$ (NPS) while organic fertilizers are not such commonly used for the production of potato and other crops [9]. Sole application of mineral fertilizers may increase soil acidity and depletion of essential 
micronutrients $[10,11]$. Organic fertilizers serve as a source of soil organic matter; improve buffering capacity of a soil; release nutrients gradually over the crop growth period and excellent supplier of balanced nutrients to plants, and also improve soil chemical, physical, and biological properties $[8,12]$. Even if it has multiple benefits, there are also several problems limiting the use of organic fertilizers by farmers to enhance soil fertility. Among the major problems, low availability of organic fertilizers, having variable quality making them difficult to standardize, and low in their nutrient contents (cannot provide the full ranges of nutrients required by crops) and high labor demand for preparation and transporting are reported by different scholars $[8,11,12]$.

Integrated soil fertility management method which involves combined application of organic and inorganic fertilizers is the best method for overcoming the shortcoming of sole use either of inorganic or organic fertilizers $[8,9,11]$. The reduction in mineral fertilizer application through their supplementation with organic sources such as coffee husk makes the use of soil nutrient amendments affordable to small holder farmers for sustainable crop production and improvement of soil health [13]. Previous research efforts focused on the effect of different combination of organic fertilizers, compost from different feedstock with different inorganic fertilizers in different area to improve potato yield and soil physiochemical properties. Wet processing of coffee constitutes around $40 \%$ of the wet weight of the fresh fruit as by-product [14] (Kivaisi and Assefa, 2010). The disposal of by-product as waste by dumping into the natural water systems or agricultural land in Ethiopia has been the major health challenges to coffee farmers living in the surroundings of coffee processing plants [15] (Weldesenbet et al., 2016). Most of the coffee pulp waste remains underutilized in many countries [16] (Nayak and Harshitha, 2012). Therefore, large amount of unutilized biomass need to be changed into value-added bioproducts such as $\mathrm{CHC}$ which could also minimize environmental problems arising from waste disposal. Coffee wastes are utilized in other coffee producing countries as soil amendments $[13,17,18]$ and researchers have shown coffee husk is rich in organic agricultural waste and $\mathrm{K}$ was good material for composting process and can be composted, made in to useful organic fertilizer, and significantly improved the supply of total $\mathrm{N}$, avail. $\mathrm{P}, \mathrm{Ca}, \mathrm{Mg}$, and $\mathrm{K}[18,19]$. However, in Chora District of Buno Bedele zone there are a number of coffee processing industries and that led to accumulation of huge amount of wasted by-product (coffee husk) deposited for a long time which have been contributing to the environmental problem. Despite these facts, almost no research has been conducted on the effect of combined use of coffee husk compost (CHC) and NPSB fertilizer on soil physicochemical properties of potato yield in general and the study area in particular. Therefore, the current study is designed to evaluate the effect of different rates of $\mathrm{CHC}$ and NPSB on selected soil chemical properties of potato field.

\section{Materials and Methods}

2.1. Description of Study Area. The field experiment was conducted at Chora District, Oromia regional state south western Ethiopia during 2021 under supplementary irrigation. The district is located $8^{\circ} 9^{\prime}, 49^{\circ} 51^{\prime}$ in the North and $35^{\circ} 6^{\prime}$ and $35^{\circ} 38^{\prime}$ East with an elevation ranging from 1450-2300 m.a.s.l and situated at about $515 \mathrm{~km}$ from Addis Ababa capital city of the country to the south western direction [3]. The experimental field is located at an elevation of 1858 m.a.s.l. and geographic coordinate of $92^{\circ} 71^{\prime}$ $70^{\prime \prime} \mathrm{N}$ and $19^{\circ} 11^{\prime} 15^{\prime \prime} \mathrm{E}$ (Figure 1). The experimental field land use history shows it was cultivated twice a year by irrigation and main rainy season for more than five years. The district has a mono modal type of rainfall and the short rainy season (the "Belg" rain) which occurs during March, April, and May and the main rainy season ("Kremt" rain) occurs in the months of June, July, and August [20]. The annual rainfall ranges between 1500 and $2200 \mathrm{~mm}$, and daily mean temperature ranges between $9 \mathrm{C}$ and $31 \mathrm{C}$ [1821]. The dominant agricultural soil group of the district is Nitisol [20]. Agroecology of the district is divided into three ecological zones, namely, low altitude (Kola) 1.5\%, mid-altitude (woyinadega) 95.1\%, and high altitude (Dega) $3.4 \%$ [21]. Potato is cultivated in the District both under irrigation and rain fed condition, but more it is produced by irrigation. From irrigated crops, it ranks first in terms of land coverage [21] and soil chemical properties of potato field.

2.1.1. Preplanting Selected Physicochemical Properties of Experimental Soil. The soil analysis result of the study area before planting indicated that it is dominated by clay soil fraction with moderate bulk density for agricultural use. The soils chemical properties of the site also revealed very strong acidity with $\mathrm{pH}(4.25 \mathrm{H} 2 \mathrm{O})$ and relatively high content of exchangeable acidity. It also had medium CEC, low amounts of organic carbon, medium in total $\mathrm{N}$, very low in available $\mathrm{P}$ and low to medium in exchangeable bases $\left(\mathrm{Ca}^{2+}, \mathrm{Mg}^{2+}, \mathrm{K}^{+}\right.$, and $\left.\mathrm{Na}^{+}\right)$, and generally poor in soil fertility. This may be attributed to the poor nutrient management coupled with continuous cultivation of the soils of the study area. The result of preplanting soil analysis is presented in Table 1.

2.2. Experimental Materials. A potato local seed tuber variety known as Aba-damu was used as test crop. The variety was evaluated by participatory variety selection in North West Ethiopia. It was preferred and cultivated by many farmers in the study District. It is characterized by medium early maturity; high water use efficiency; nice looking tubers; and long-term storability and it is predominant variety in submoist agroecology and adaptation to low soil fertility [27].

Blended NPSB fertilizer $(18.9 \mathrm{~N}+37.7 \mathrm{P}+6.94 \mathrm{~S}+0.15 \mathrm{~B}$ in the form of $\mathrm{NH}_{4}, \mathrm{P}_{2} \mathrm{O}_{5}, \mathrm{SO}_{4}^{-}$, and $\mathrm{B}_{2} \mathrm{O}_{5}$ ) was used as a mineral fertilizer source. The blended fertilizer is recommended for the soils of the District by ATA (soil fertility status and fertilizer recommendation map available at District) [28]. Coffee husk compost was used as an organic fertilizer source. It is cocomposted with bioslurry in the ratio of $3: 1$ coffee husk to bioslurry in the pit. 


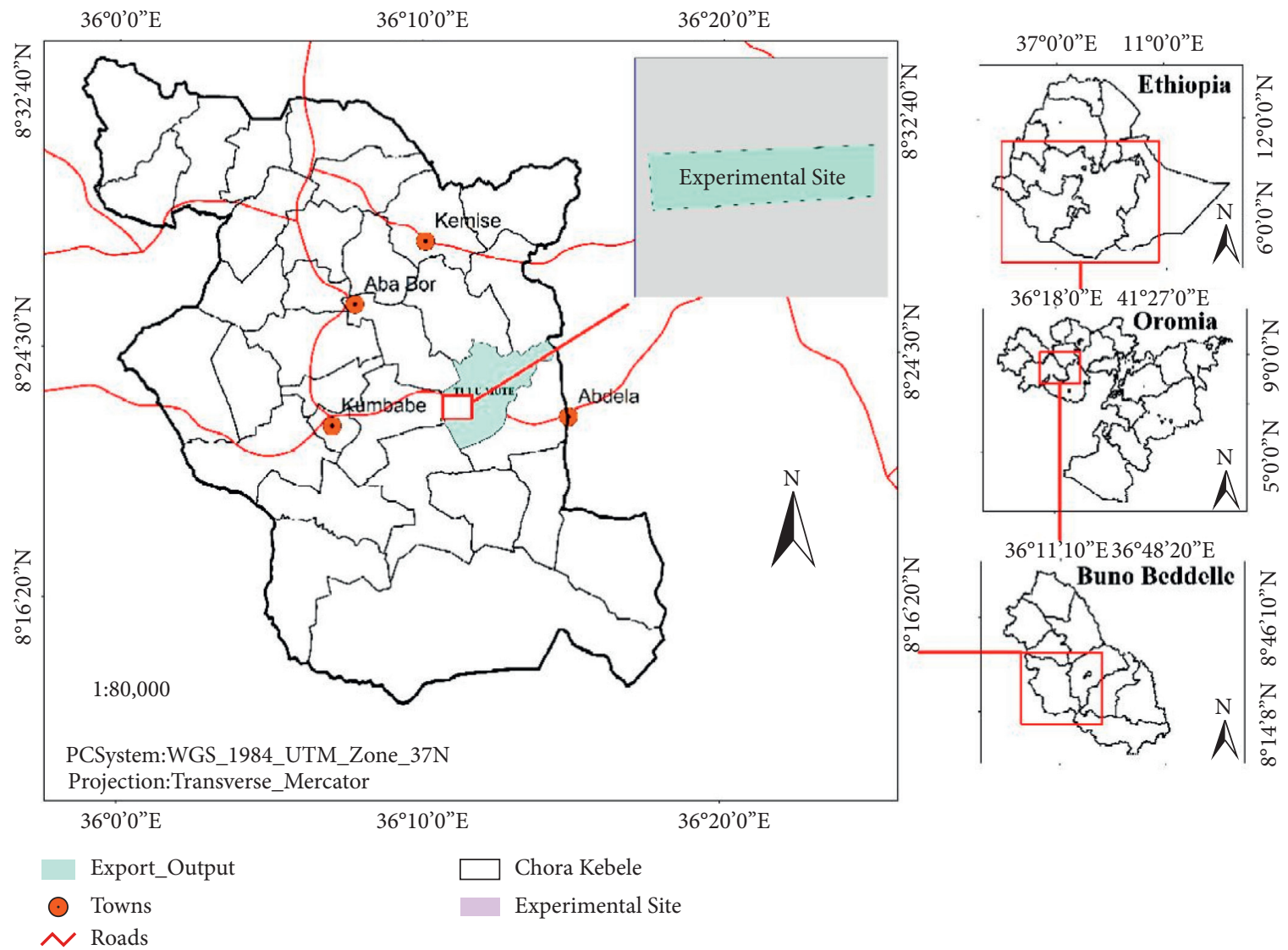

Figure 1: Map of study area.

TABLe 1: Preplanting selected soil physicochemical properties of experimental soil.

\begin{tabular}{|c|c|c|c|c|}
\hline \multicolumn{2}{|l|}{ Physicochemical properties } & Value & Rating & Source \\
\hline \multicolumn{5}{|c|}{ Chemical properties } \\
\hline $\mathrm{pH}\left(\mathrm{H}_{2} \mathrm{O}\right)$ & & 4.25 & Highly acidic & Tadese [22] \\
\hline Organic carbon (\%) & & 4.54 & Moderate & Tadese [22] \\
\hline Total nitrogen $(\%)$ & & 0.14 & Medium & Murphy [23] \\
\hline Avail. P (ppm or $\mathrm{mg} \mathrm{kg}^{-1}$ & & 0.95 & Low & Olsen et al. [24] \\
\hline Avail. sulfur (ppm) & & 2.98 & - & \\
\hline Exchangeable acidity (mec & & 0.60 & - & \\
\hline $\mathrm{CEC}\left(\mathrm{meq} 100 \mathrm{~g}^{-1}\right)$ & & 12.05 & Low & Hazelton and Murphy [25] \\
\hline \multirow{4}{*}{ Exchangeable base } & $\mathrm{Ca}^{2+}\left(\right.$ meq $\left.100 \mathrm{~g}^{-1}\right)$ & 18.42 & High & FAO $[26]$ \\
\hline & $\mathrm{Mg}^{2+}\left(\right.$ meq $\left.100 \mathrm{~g}^{-1}\right)$ & 8.09 & High & FAO [26] \\
\hline & $\mathrm{Na}+\left(\mathrm{meq} 100 \mathrm{~g}^{-1}\right)$ & 0.02 & Very low & FAO [26] \\
\hline & $\mathrm{K}+\left(\mathrm{meq} 100 \mathrm{~g}^{-1}\right)$ & 0.61 & Medium & FAO [26] \\
\hline \multirow{4}{*}{ Particle size distribution } & & prope & & \\
\hline & Clay\% & 52.50 & & \\
\hline & Silt $\%$ & 27.50 & & \\
\hline & Sand $\%$ & 20.00 & & \\
\hline \multirow{2}{*}{\multicolumn{2}{|c|}{ Bulk density $\left(\mathrm{g} \mathrm{cm}^{3-1}\right)$ Soil textural }} & & Clay & \\
\hline & & 1.23 & Moderate & Hazelton and Murphy [25] \\
\hline
\end{tabular}

Source: soil laboratory analysis result report for preplanting physicochemical properties.

2.3. Chemical Composition of CHC before Planting. Coffee husk compost was used as an organic fertilizer source. The $\mathrm{CHC}$ used in this study is cocomposted with bioslurry to shorten the decomposition period of coffee husk and to minimize $\mathrm{N}$ loss from bioslurry. It is prepared with the ratio of $3: 1$ coffee husk to bioslurry in the pit, turned two times, and incubated for decomposition for 60 days. The chemical compositions of $\mathrm{CHC}$ prior to planting were $7.86 \mathrm{pH}(1: 10$ $\mathrm{H}_{2} \mathrm{O}$ ), which is moderately alkaline in reaction, $11.7 \%$, $0.371 \%$, and 30.34 ppm organic carbon, total $\mathrm{N}$, and total $\mathrm{P}$ content, respectively, and $23.85 \mathrm{meq} 100 \mathrm{~g}^{-1}$ CEC as presented in Table 2. 
TABLE 2: Chemical properties and nutrient concentrations of utilized $\mathrm{CHC}$ value.

\begin{tabular}{|c|c|}
\hline Chemical properties & Mean value \\
\hline $\mathrm{pH}\left(\mathrm{H}_{2} \mathrm{O}\right)$ & 7.86 \\
\hline Total organic carbon (\%) & 11.7 \\
\hline Total $N(\%)$ & 0.37 \\
\hline Available P (ppm) & 30.34 \\
\hline Available sulfur (ppm) & 213.28 \\
\hline Cation exchange capacity (meq100 $\mathrm{g}^{-1}$ ) & 23.85 \\
\hline \multicolumn{2}{|l|}{ Exchangeable base } \\
\hline $\mathrm{Na}^{+}(\%)$ & 0.06 \\
\hline $\mathrm{K}^{+}(\%)$ & 3.40 \\
\hline Exch. $\mathrm{Ca}^{2+}\left(\mathrm{meq} 100 \mathrm{~g}^{-1}\right)$ & 27.49 \\
\hline Exch. $\mathrm{Mg}^{2+}\left(\mathrm{meq} 100 \mathrm{~g}^{-1}\right)$ & 16.43 \\
\hline
\end{tabular}

2.4. Treatments and Experimental Design. The treatment consisted of four rates of blended NPSB $(0,75 \%, 100 \%$, and $125 \%$ of $150 \mathrm{~kg}$ of NPSB) and four rates of well-prepared CHC (0, 2.5 tha $\mathrm{th}^{-1}, 5 \mathrm{tha}^{-1}$, and $\left.7.5 \mathrm{tha}^{-1}\right)$; that is, $0,151.9$, 202.5, and 253.1 $\mathrm{g}$ NPSB per plot and $0,3.375,6.750$, and $10.125 \mathrm{~kg}$ per experimental plot $\left(13.5 \mathrm{~m}^{2}\right)$ was applied. The field experiment was laid out in a Randomized Complete Block Design (RCBD) with three replications. The experimental plot size was $3 \mathrm{~m}$ length with $4.5 \mathrm{~m}$ width accommodating six rows, 10 potatoes in each row. The planting space was $0.75 \mathrm{~m}$ and $0.3 \mathrm{~m}$ between rows and plant, respectively [29]. The spacing between adjacent blocks and adjacent plots were $1.0 \mathrm{~m}$ and $0.50 \mathrm{~m}$, respectively.

2.5. Experimental Procedures and Management. Coffee husk compost was applied and incorporated a month before planting as per the treatment. The plots were irrigated just after incorporation of the $\mathrm{CHC}$ and monitored at field capacity till potatoes planting to facilitate decomposition and mineral release. The inorganic fertilizer NPSB was applied once at planting time as per the treatment by hand drilling in the open furrow. The potato seed tubers were planted by sprouts facing upwards in the prepared open rows manually maintaining recommended planting space and depth on January 21/2021. All the required management practices were done uniformly for all plots as per farmer's experience.

\subsection{Data Collection}

2.6.1. Soil Sampling and Analysis. The preplanting and the postharvest soil data were collected. The preplanting soil samples were taken and analyzed for the selected soil physicochemical properties. The samples were randomly taken using auger to a depth of $0-30 \mathrm{~cm}$ from 20 spots of entire experimental field in zigzag pattern. The bulk density of the soil was measured from the undisturbed soil using core sampler. At harvest, one composite sample was taken from each plot making a total of 48 samples. The collected and composited soil samples were bagged, labeled, and taken to laboratory for preparation and analysis of the selected soil properties. The subsamples of composite samples were air dried and then ground with a pestle and mortar, to pass through $2 \mathrm{~mm}$ sieve in preparation except for soil organic carbon (SOC) and total $\mathrm{N}$ which passes through $0.5 \mathrm{~mm}$ sieve for the analysis. The samples were analyzed for selected soil chemical properties: $\mathrm{pH}$, organic carbon, total $\mathrm{N}$, available $\mathrm{P}$, available $\mathrm{S}, \mathrm{CEC}$, exchangeable acidity, exchangeable base $\left(\mathrm{Ca}^{2+}, \mathrm{Mg}^{2+}, \mathrm{K}^{+}\right.$, and $\left.\mathrm{Na}^{+}\right)$, and the physical soil properties: bulk density and particle size distribution. Except for available $\mathrm{S}$, exchangeable $\mathrm{Na}^{+}$, exchangeable $\mathrm{K}^{+}$, and texture analyzed at Holeta Research Center, all other parameters were analyzed at Bedele Research Center soil laboratory, Ethiopia.

The soil $\mathrm{pH}$ was measured in $1: 2.5$ soils: water ratio using a combined glass electrode by digital $\mathrm{pH}$ meter [30]. Soil organic carbon was determined by wet oxidation procedure of Walkley Black method [31], and total $\mathrm{N}$ content of the soil was determined by wet-oxidation procedure of the Kjeldahl method [32]. Available P was determined by Olsen method [24]. Available S was determined by turbidity and colorimetry [33]. Exchangeable acidity $\left(\mathrm{Al}^{+}\right.$ and $\mathrm{H}^{+}$) was determined by saturating the soil samples with $1 \mathrm{M} \mathrm{KCl}$ at $\mathrm{pH} 7$ solution and titrated with $0.02 \mathrm{M} \mathrm{NaOH}$ as described by Rowell [34]. Cation exchange capacity (CEC) and exchangeable bases were extracted by saturating the sample with $1 \mathrm{~N}$ ammonium acetate $\left(\mathrm{NH}_{4} \mathrm{O}\right)$ at $\mathrm{pH}$ 7. Exchangeable $\mathrm{Ca}$ and $\mathrm{Mg}$ were determined by using atomic absorption spectrophotometry (AAS), while exchangeable $\mathrm{Na}$ and $\mathrm{K}$ were analyzed by ammonium acetate extraction using atomic absorption spectrophotometry (AAS) [35].

Soil texture was determined using Bouyoucos hydrometer method [36] and soil bulk density $(\rho \mathrm{b})$ was measured and determined by measuring the volume of undisturbed soil sample collected using a core sampler and sample was weighed after oven dried at temperature of $105^{\circ} \mathrm{C}$. Then, the result was calculated by using the formula (equation (1)) as procedure described by Jamison et al. [37].

$$
\rho b=\frac{\text { mass of soil in gram }}{\text { volume of soil in } \mathrm{cm}^{3}} \text {. }
$$

2.6.2. Coffee Husk Compost Sampling and Analysis. The $\mathrm{CHC}$ samples were analyzed for the chemical parameters such as $\mathrm{pH}$, organic carbon, total $\mathrm{N}$, available $\mathrm{P}$, available $\mathrm{K}$, and available $\mathrm{S}$ contents as per standard procedures. Composite sample of 10 gram with three replicates per pile was taken, dried, and ground to pass through a $2 \mathrm{~mm}$ sieve as described by Pisa and Menas [38]. Soil pH was determined from a suspension of $1: 10 \mathrm{CHC}: \mathrm{H}_{2} \mathrm{O}$ as described by Ndegwa and Thompson [39]. The total OC was estimated by wet digestion and rapid titration method [31]. The total $\mathrm{N}$ content of the CHC was determined by wet-oxidation procedure of the Kjeldahl method (Bremner and Mulvaney, 1982). Total $\mathrm{P}$ was extracted using concentrated $\mathrm{H}_{2} \mathrm{SO}_{4}$, Se powder, salicylic acid $\left(\mathrm{C}_{7} \mathrm{H}_{6} \mathrm{O}_{3}\right)$, and $\mathrm{H}_{2} \mathrm{O}_{2}$ mixture and finally read by using the UV spectroscopy [40]. Total $\mathrm{Ca}, \mathrm{Mg}$, $\mathrm{K}$, and $\mathrm{Na}$ was extracted by wet digestion using concentrated sulfuric acid $\left(\mathrm{H}_{2} \mathrm{SO}_{4}\right)$, selenium ( $\mathrm{Se}$ ) powder, lithium sulfate $\left(\mathrm{Li}_{2} \mathrm{SO}_{4}\right)$, and hydrogen peroxide $\left(\mathrm{H}_{2} \mathrm{O}_{2}\right)$ mixture [40]. Total $\mathrm{Ca}$ and $\mathrm{Mg}$ were determined from the wet digested samples by AAS while exchangeable $\mathrm{Na}$ and $\mathrm{K}$ were analyzed by 
ammonium acetate extraction using atomic absorption spectrophotometry [35].

2.7. Statistical Analysis. Collected postharvest soil data were subjected to analysis of variance (ANOVA) using SAS software (version 9.4). The Generalized Liner Model (GLM) procedure was employed to detect variation among treatments. Mean separation of significant treatments performed using the Least Significant Difference test (LSD) $(p<0.05)$.

\section{Result and Discussion}

\subsection{Postharvest Soil Chemical Properties}

3.1.1. Soil $p H$. The soil $\mathrm{pH}$ was high significantly $(p<0.05)$ affected by the main factors of CHC and NPSB fertilizers as well as their interaction (Table 3). The result of the analysis revealed that the highest soil $\mathrm{pH}\left(5.30 \mathrm{H}_{2} \mathrm{O}\right)$ was recorded from application of $7.5 \mathrm{tha}^{-1} \mathrm{CHC}$ alone, while the lowest soil $\mathrm{pH}\left(4.03 \mathrm{H}_{2} \mathrm{O}\right)$ was recorded from sole application of NPSB fertilizer at a rate of $187.5 \mathrm{~kg} \mathrm{ha}^{-1}$. The result shows improvement in soil $\mathrm{pH}$ by $24 \%$ and $31.5 \%$ due to application of $7.5 \mathrm{tha}^{-1} \mathrm{CHC}$ alone with reference to the control and highest rate of NPSB fertilizer applied treatment. On the other hand, the highest rate of $\mathrm{CHC}$ improved the soil $\mathrm{pH}$ by $24.7 \%$ while the highest rate of blended chemical fertilizer dropped the soil $\mathrm{pH}$ by $5.2 \%$ when compared to initial soil $\mathrm{pH}$ (Tables 1 and 3).

This might be because of the amendment of the soil with $\mathrm{CHC}$ and its ability to raise soil $\mathrm{pH}$ due to addition of basic cations, ammonification and production of $\mathrm{NH}_{3}$ during decomposition of added compost, adsorption of $\mathrm{H}^{+}$ions, and increased microbial activity as a result of organic matter application and break down of organic matter for energy source and nutrient recycling [41]. The beneficial effect of $\mathrm{CHC}$ application to the soil is its potential to increase the soil $\mathrm{pH}$ [13]. The result is in agreement with the finding of Dzung et al. [18] who reported application of compost prepared from coffee husk improved the fertility of the soil and $\mathrm{pH}$ of the soil. The present result is also consistent with the finding of Islam et al. [42] that investigate maximum increase in acidity in treatments having the highest dose of inorganic fertilizers and treatments amended with the poultry manure (PM) resulted in raised soil $\mathrm{pH}$. The lowering of soil $\mathrm{pH}$ in the plot that received high rate of blended chemical fertilizers as compared to the preplanting soil $\mathrm{pH}$ in this experiment might be due to uptake of base cations with the crops and the simultaneous increase of leaching which takes place when soils are disturbed and worked $[43,44]$. During growth, crops absorb basic elements such as $\mathrm{Ca}, \mathrm{Mg}$, and $\mathrm{K}$ to satisfy their nutritional requirements which results in increasing soil acidity [45].

3.1.2. Soil Organic Carbon (OC). The soil analysis result revealed that soil organic carbon content was significantly $(p<0.01)$ affected by the main factor $\mathrm{CHC}$ and its interactions with NPSB fertilizer (Table 3). Coffee husk compost amended plot in all rates (sole and combined) showed improvement in organic carbon content and the highest soil organic carbon content (6\%) was obtained from sole application of CHC at a rate of $7.5 \mathrm{tha}^{-1}$ which is statistically similar with plots amended with combined application of either of 5 and $7.5 \mathrm{tha}^{-1}$ CHC with 112.5, 150, and $187.5 \mathrm{~kg} \mathrm{ha}^{-1}$ fertilizers while the lowest soil organic carbon (4.1 and 4.5) was recorded from the plot supplied with high rate of sole NPSB fertilizer and control plots, respectively. Also the highest rate of $\mathrm{CHC}$ application improved the soil organic carbon content of preplanting soils by $32 \%$ (from 4.54 to 6.00 ) while the highest rate of blended chemical fertilizer application reduced the soil organic carbon content by $9.7 \%$ (from 4.54 to 4.1 ) (Tables 1 and 3 ). This might be attributed to high amount of organic matter in compost increases OC content in soil and application of $\mathrm{CHC}$ to soil improves OC\%. Dzung et al. [18] also reported in particular, application of compost prepared from coffee husk enhanced OC\% significantly in comparison with the control. Getinet [46] also reported that application of $\mathrm{CHC}$ to soil improves OC\%.

3.1.3. Total Soil Nitrogen $(N)$. The total soil $\mathrm{N}$ was significantly $(p<0.05)$ influenced by the application of the main factors of CHC and NPSB fertilizer and their interaction (Table 3). The highest soil total $\mathrm{N}(0.26 \%)$ was recorded from the combined application of $7.5 \mathrm{tha}^{-1} \mathrm{CHC}$ and $187.5 \mathrm{~kg} \mathrm{ha}^{-1}$ NPSB fertilizer followed by the combined application of $7.5 \mathrm{tha}^{-1} \mathrm{CHC}$ and $150 \mathrm{~kg} \mathrm{ha}^{-1}$ NPSB fertilizer while the lowest soil total $\mathrm{N}(0.12 \%)$ was recorded from control treatment. It is also observed from the experimental result that total soil $\mathrm{N}$ improved by $85.7 \%$ (from 0.14 to $0.26 \%$ ) while depleted by $14 \%$ (from 0.14 to $0.12 \%$ ) when compared to initial total soil $\mathrm{N}$ content (Tables 1 and 3 ).

This might be resulted from potential of incorporated $\mathrm{CHC}$ to increase total $\mathrm{N}$ content due to ammonification and production of $\mathrm{NH}_{3}$ during decomposition of the added compost [41]; the $\mathrm{N}$ content in the $\mathrm{CHC}$ is more $\mathrm{N}$ than the $\mathrm{N}$ content in common organic fertilizers [17]; release and mineralization of $\mathrm{N}$ over a time as a result of decomposed CHC applied [13] increased activities of soil microbes that enhances release of $\mathrm{N}$ [47] and decreased leaching of $\mathrm{N}$ as a result of compost application [41] and also due to use of balanced fertilizers (integration of CHC and NPSB) as balanced fertilization is the key to maintain soil health and improve nutrient availability [48]. The result is in agreement with Chali [49]; Dzung et al. [18]; and Solomon et al. [50] who reported that $\mathrm{CHC}$ do release $\mathrm{N}$ into soil when used alone or in combination with inorganic fertilizer and improve soil total $\mathrm{N}$.

3.1.4. Soil Available Phosphorus (P). The analysis result also indicated that soil available $\mathrm{P}$ was significantly $(p<0.01)$ affected by the main factors of CHC and NPSB fertilizer and their interaction (Table 4). The highest available $\mathrm{P}$ (3.57 ppm) was obtained from the combined application of $7.5 \mathrm{tha}^{-1} \mathrm{CHC}$ and $187.5 \mathrm{~kg} \mathrm{ha}^{-1}$ NPSB fertilizer while the lowest available $\mathrm{P}(0.95 \mathrm{ppm})$ was recorded from control treatment. The combined application $7.5 \mathrm{tha}^{-1} \mathrm{CHC}$ and 
TABLE 3: Interaction effect of CHC and NPSB fertilizer on soil chemical properties of potato field soil.

\begin{tabular}{|c|c|c|c|c|c|c|c|}
\hline \multicolumn{2}{|c|}{ Treatment } & \multirow{2}{*}{$\mathrm{pH}\left(\mathrm{H}_{2} \mathrm{O}\right)$} & \multirow{2}{*}{ OC (\%) } & \multirow{2}{*}{ TN (\%) } & \multirow{2}{*}{ Av. P (ppm) } & \multirow{2}{*}{ Av. S (ppm) } & \multirow{2}{*}{ Ex. acidity (meq $100 \mathrm{~g}^{-1}$ ) } \\
\hline $\mathrm{CHC}$ & NPSB & & & & & & \\
\hline 0 & 0 & $4.26^{\mathrm{g}}$ & $4.52^{\mathrm{f}}$ & $0.12^{\mathrm{i}}$ & $0.95^{j}$ & $3.01^{\mathrm{f}}$ & $0.76^{\mathrm{b}}$ \\
\hline 0 & 112.5 & $4.27^{\mathrm{g}}$ & $5.22^{\text {cde }}$ & $0.15^{\mathrm{h}}$ & $1.02^{\mathrm{j}}$ & $3.60^{\mathrm{de}}$ & $0.80^{\mathrm{b}}$ \\
\hline 0 & 150.0 & $4.20^{\mathrm{g}}$ & $4.87^{\mathrm{ef}}$ & $0.17^{\text {efg }}$ & $1.47^{\mathrm{i}}$ & $3.64^{\text {cde }}$ & $0.84^{\mathrm{a}}$ \\
\hline 0 & 187.5 & $4.03^{\mathrm{h}}$ & $4.10^{\mathrm{g}}$ & $0.15^{\mathrm{gh}}$ & $2.09^{\mathrm{h}}$ & $3.72^{\text {bcde }}$ & $0.85^{\mathrm{a}}$ \\
\hline 2.5 & 0 & $4.52^{\mathrm{ef}}$ & $5.30^{\mathrm{bcd}}$ & $0.16^{\text {fgh }}$ & $1.12^{\mathrm{j}}$ & $3.51^{\mathrm{e}}$ & $0.53^{\mathrm{de}}$ \\
\hline 2.5 & 112.5 & $4.51^{\mathrm{ef}}$ & $5.00^{\mathrm{de}}$ & $0.20^{\mathrm{de}}$ & $2.42^{\mathrm{g}}$ & $3.72^{\text {bcde }}$ & $0.65^{\mathrm{c}}$ \\
\hline 2.5 & 150.0 & $4.53^{\mathrm{ef}}$ & $5.60^{\mathrm{abc}}$ & $0.18^{\mathrm{e}}$ & $2.63^{\text {efg }}$ & $3.82^{\mathrm{bcd}}$ & $0.58^{\mathrm{d}}$ \\
\hline 2.5 & 187.5 & $4.49^{\mathrm{f}}$ & $5.67^{\mathrm{ab}}$ & $0.19^{\mathrm{de}}$ & $2.50^{\mathrm{fg}}$ & $3.85^{\mathrm{bc}}$ & $0.52^{\mathrm{e}}$ \\
\hline 5 & 0 & $4.72^{\mathrm{d}}$ & $5.80^{\mathrm{a}}$ & $0.16^{\mathrm{fgh}}$ & $1.17^{\mathrm{j}}$ & $3.72^{\text {bcde }}$ & $0.33^{\mathrm{g}}$ \\
\hline 5 & 112.5 & $4.63^{\mathrm{de}}$ & $5.70^{\mathrm{ab}}$ & $0.18^{\mathrm{ef}}$ & $2.57^{\mathrm{fg}}$ & $3.79^{\mathrm{bcd}}$ & $0.32^{\mathrm{g}}$ \\
\hline 5 & 150.0 & $4.62^{\mathrm{de}}$ & $5.77^{\mathrm{a}}$ & $0.18 \mathrm{e}$ & $2.69^{\mathrm{def}}$ & $4.13^{\mathrm{a}}$ & $0.52^{\mathrm{e}}$ \\
\hline 5 & 187.5 & $4.57 \mathrm{ef}$ & $5.73^{\mathrm{a}}$ & $0.21^{\mathrm{cd}}$ & $2.83^{\text {cde }}$ & $4.23^{\mathrm{a}}$ & $0.53^{\mathrm{de}}$ \\
\hline 7.5 & 0 & $5.30 \mathrm{a}$ & $6.00^{\mathrm{a}}$ & $0.18^{\mathrm{e}}$ & $2.90^{\mathrm{cd}}$ & $3.84^{\mathrm{bc}}$ & $0.32^{\mathrm{g}}$ \\
\hline 7.5 & 112.5 & $5.22 \mathrm{ab}$ & $5.87^{\mathrm{a}}$ & $0.23 b c$ & $3.02^{\mathrm{c}}$ & $3.92^{\mathrm{b}}$ & $0.44^{\mathrm{f}}$ \\
\hline 7.5 & 150.0 & $5.13 \mathrm{~b}$ & $5.93^{\mathrm{a}}$ & $0.24^{\mathrm{ab}}$ & $3.31^{\mathrm{b}}$ & $4.15^{\mathrm{a}}$ & $0.44^{\mathrm{f}}$ \\
\hline 7.5 & 187.5 & $4.97 \mathrm{c}$ & $5.90^{\mathrm{a}}$ & $0.26^{\mathrm{a}}$ & $3.57^{\mathrm{a}}$ & $4.36^{\mathrm{a}}$ & $0.55^{\mathrm{de}}$ \\
\hline \multicolumn{2}{|c|}{$F$-test } & $*$ & $* * *$ & $*$ & $* * *$ & $*$ & $* * *$ \\
\hline \multicolumn{2}{|c|}{ LSD (0.05) } & 0.11 & 0.38 & 0.02 & 0.24 & 0.21 & 0.05 \\
\hline \multicolumn{2}{|c|}{ CV (\%) } & 1.46 & 4.16 & 7.511 & 6.22 & 3.25 & 5.71 \\
\hline
\end{tabular}

Means sharing the same letter within a column are not significantly different according to LSD at $5 \%$ level of significance; CV $=$ coefficient of variation; ${ }^{*}=$ significant at $p=0.05 ;{ }^{* *}=$ significant at $p=0.01 ;{ }^{* * *}=$ significant at $p=0.001 ; \mathrm{OC}=$ organic carbon; TN $=$ total nitrogen; Av. $\mathrm{P}=$ available phosphorus; Av. $S=$ available sulfur; Ex. acidity $=$ exchangeable acidity.

TABLE 4: The main effect of CHC and NPSB fertilizers on exchangeable $\mathrm{K}^{+}$and $\mathrm{Na}^{+}$of soils of potato field.

\begin{tabular}{|c|c|c|}
\hline Treatment & Exch.K $\mathrm{K}^{+}\left(\right.$meq $\left.100 \mathrm{~g}^{-1}\right)$ & Exch. $\mathrm{Na}^{+}$(meq $100 \mathrm{~g}^{-1}$ ) \\
\hline \multicolumn{3}{|c|}{$\mathrm{CHC}\left(\mathrm{t} \mathrm{ha}^{-1}\right)$} \\
\hline 0 & $0.61^{\mathrm{d}}$ & $0.032^{\mathrm{d}}$ \\
\hline 2.5 & $1.56^{\mathrm{c}}$ & $0.036^{\mathrm{c}}$ \\
\hline 5 & $1.87^{\mathrm{b}}$ & $0.040^{\mathrm{b}}$ \\
\hline 7.5 & $2.12^{\mathrm{a}}$ & $0.054^{\mathrm{a}}$ \\
\hline F test & *** & *** \\
\hline \multicolumn{3}{|c|}{ NPSB $\left(\mathrm{kg} \mathrm{ha}^{-1}\right)$} \\
\hline 0 & $1.72^{\mathrm{a}}$ & $0.040^{\mathrm{a}}$ \\
\hline 112.5 & $1.62^{\mathrm{a}}$ & $0.039^{\mathrm{a}}$ \\
\hline 150 & $1.50^{\mathrm{b}}$ & $0.041^{\mathrm{a}}$ \\
\hline 187.5 & $1.32^{\mathrm{c}}$ & $0.041^{\mathrm{a}}$ \\
\hline F test & $* * *$ & NS \\
\hline LSD & 0.097 & 0.002 \\
\hline CV (\%) & 7.54 & 6.24 \\
\hline
\end{tabular}

Means sharing the same letter within a column are not significantly different according to LSD at $5 \%$ level of significance; $C V=$ coefficient of variation; ${ }^{* * *}=$ significant at $p=0.001 ;{ }^{\mathrm{NS}}=$ not significant; Exch. $\mathrm{K}^{+}=$exchangeable potassium; Exch. $\mathrm{Na}^{+}=$exchangeable sodium.

$187.5 \mathrm{~kg} \mathrm{ha}^{-1}$ NPSB fertilizers also improved the soil available $\mathrm{P}$ by more than $100 \%$ (from 0.95 to 3.57 ) while in control plot soil available P was depleted by $1 \%$ (from 0.95 to $0.94 \mathrm{ppm}$ ) when compared to initial soil available P (Tables 1 and 3 ).

This result might be related to significantly increased soil $\mathrm{pH}$ due to the application of $\mathrm{CHC}$ and released available $\mathrm{P}$ and other basic cations from the compost to the soil [17] and also due to the beneficial effect of $\mathrm{CHC}$ application preventing $\mathrm{P}$ fixation in the soil [13]. The result is in agreement with Bikila [51] who reported application of $\mathrm{CHC}$ increase in available $\mathrm{P}$ contents of the soil. Dzung et al. [18] and
Solomon et al. [50] also reported that $\mathrm{CHC}$ release $\mathrm{P}$ into soil when used alone or in combination with inorganic fertilizer and improve soil available $\mathrm{P}$.

3.1.5. Available Sulfur (S). The analysis result also revealed that soil available $S$ was significantly $(p<0.05)$ influenced by the main factors of CHC and NPSB fertilizer and their interaction (Table 3$)$. The highest available $S$ ( $4.36 \mathrm{ppm}$ ) was obtained from the treatment supplied with combined application of $7.5 \mathrm{tha}^{-1} \mathrm{CHC}$ and $187.5 \mathrm{~kg} \mathrm{ha}^{-1}$ NPSB fertilizer which is statistically similar with the treatments received combination of $5 \mathrm{tha}^{-1} \mathrm{CHC}$ with either of 150 and $187.5 \mathrm{~kg} \mathrm{ha}^{-1}$ NPSB fertilizer as well as $7.5 \mathrm{tha}^{-1} \mathrm{CHC}$ and $150 \mathrm{~kg} \mathrm{ha}^{-1}$ NPSB fertilizer while the lowest available S (3.01 ppm) was recorded from control treatment. On the other hand, the initial soil available $\mathrm{S}$ was improved by $46 \%$ (from 2.98 to $4.36 \mathrm{ppm}$ ) with combined application of $7.5 \mathrm{tha}^{-1} \mathrm{CHC}$ and $187.5 \mathrm{~kg} \mathrm{ha}^{-1}$ NPSB fertilizers (Table 3 and Table 1). This result might be related to balanced fertilization of the applications of blended NPSB fertilizer and $\mathrm{CHC}$ influence apparent nutrient recovery of soil [11]. The result is in agreement with the result of Gemechu [49] who suggested moderate applications of CHC and NPS fertilizer supply adequate soil $\mathrm{S}$ levels to soil.

3.1.6. Exchangeable Acidity. The exchangeable acidity was also significantly $(p<0.01)$ affected by the main factors of $\mathrm{CHC}$ and NPSB fertilizer and their interaction (Table 3 ). The result of the analysis indicates that the highest exchangeable acidity ( 0.85 meq $100 \mathrm{~g}^{-1}$ ) was recorded from treatment supplied with $187.5 \mathrm{~kg} \mathrm{ha}^{-1}$ NPSB fertilizer alone and this is statistically similar with plot supplied with $150 \mathrm{~kg} \mathrm{ha}^{-1} \mathrm{NPSB}$ 
fertilizer alone while the lowest exchangeable acidity $(0.32$ meq $100 \mathrm{~g}^{-1}$ ) was recorded from treatment supplied with $7.5 \mathrm{tha}^{-1} \mathrm{CHC}$ alone which is statistically similar with treatment received sole application of $5 \mathrm{tha}^{-1} \mathrm{CHC}$ and combined application of $5 \mathrm{tha}^{-1} \mathrm{CHC}$ with $112.5 \mathrm{~kg} \mathrm{ha}^{-1}$ NPSB fertilizer (Table 3). The highest rate of $\mathrm{CHC}$ reduces the soil exchangeable acidity value by $87.5 \%$ (from 0.60 to 0.32 ) while the highest rate of blended chemical fertilizer increased the soil exchangeable acidity value by $30 \%$ (from 0.60 to 0.85 ) when compared to initial soil exchangeable acidity (Tables 1 and 3).

The result indicated improvement in exchangeable acidity over sole application of NPSB fertilizer and control plot with application of sole $\mathrm{CHC}$ and in combination with NPSB fertilizer while medium and highest rate of sole NPSB fertilizer application increases exchangeable acidity. This might be because of raised soil $\mathrm{pH}$ as a result of CHC application (in sole and combined) that reduces exchangeable acidity and potential effect of sole application of inorganic fertilizer in increasing exchangeable acidity. The result is consistent with the result of Bikila [51] that recommended organic amendment sources which are easily available (coffee husk) should be encouraged to increase productivity of the acidic soils in western Ethiopia. It also similar with the result of Gemechu [49] who reported application of CHC along with inorganic fertilizers minimizes exchangeable acidity. Kasongo et al. [17] and Nduka et al. [13] also suggested application of $\mathrm{CHC}$ to tropical soils has shown that it has the potential to be used as a liming material and as inorganic fertilizer because of its mineral content compositions such as $\mathrm{N}, \mathrm{P}, \mathrm{K}, \mathrm{Mg}, \mathrm{Ca}$, and $\mathrm{Na}$.

3.1.7. Cation Exchange Capacity (CEC). The cation exchangeable capacity of the soil was significantly $(p<0.05)$ influenced by the main factors of CHC and NPSB fertilizer and their interactions (Table 5). The highest CEC (14.08 meq $100 \mathrm{~g}^{-1}$ ) was obtained from the combined application of $7.5 \mathrm{tha}^{-1} \mathrm{CHC}$ and $150 \mathrm{~kg} \mathrm{ha}^{-1}$ NPSB fertilizers which is statistically similar with combination of $7.5 \mathrm{tha}^{-1} \mathrm{CHC}$ with either of 112.5 and $187.5 \mathrm{~kg} \mathrm{ha}^{-1}$ and sole application of $7.5 \mathrm{tha}^{-1}$ CHC while the lowest CEC (12.05 meq $\left.100 \mathrm{~g}^{-1}\right)$ was recorded from the treatment supplied with highest rate of NPSB fertilizer which at par with treatment supplied with sole NPSB fertilizer and control (Table 5). Moreover, the highest rate of $\mathrm{CHC}$ application improved the initial soil CEC by $17 \%$ (from 12.05 to 14.10) (Tables 1 and 5).

This might be related to the increase in organic matter contents and available nutrients with the applied $\mathrm{CHC}$ and also direct correlation between organic matter and cation exchange capacity of the soil. It may also due to high content of CEC of compost and thus increase soil CEC when incorporated [41]. Compost amended soil resulted in an increase of CEC due to input of stabilized organic matter (CHC) [11]. The result is consistent with the findings of Dzung et al. [18] and Chali [49] and those reported application of $\mathrm{CHC}$ to soil increases soil cationic exchange capacity. Takala Dibaba et al. [52] also reported promising potential of CHC amendment alone or in combination with conventional lime to ameliorate soil acidity, CEC, and improve nutrient availability on acidic soil.

3.1.8. Exchangeable Calcium $\left(\mathrm{Ca}^{2+}\right)$. The exchangeable $\mathrm{Ca}$ was significantly $(p<0.01)$ influenced by the application of the main factors CHC and NPSB fertilizers and their interaction (Table 5). The highest exchangeable Ca $(23.22 \mathrm{meq}$ $100 \mathrm{~g}^{-1}$ ) was recorded from the combined application of $7.5 \mathrm{tha}^{-1} \mathrm{CHC}$ and $150 \mathrm{~kg} \mathrm{ha}^{-1}$ NPSB fertilizer, while the lowest exchangeable $\mathrm{Ca}\left(18.17 \mathrm{meq} 100 \mathrm{~g}^{-1}\right)$ was recorded from the plot supplied with $112.5 \mathrm{~kg} \mathrm{ha}^{-1}$ NPSB fertilizer alone which is statistically similar with sole application of NPSB fertilizer and control (Table 5). On the other hand, the combined application of $7.5 \mathrm{tha}^{-1} \mathrm{CHC}$ and $150 \mathrm{~kg} \mathrm{ha}^{-1}$ NPSB fertilizer improved the initial soil exchangeable $\mathrm{Ca}^{2+}$ by $26 \%$ (from 18.42 to 23.22 ) (Tables 1 and 5 ).

The improvement in exchangeable $\mathrm{Ca}$ over control and sole NPSB fertilizer with the application of sole CHC and in combination with NPSB fertilizer might be due to release of $\mathrm{Ca}^{2+}$ from applied CHC to soil and potential effect of CHC in nutrient retention. Kasongo et al. [17] also investigated the efficiency of coffee waste to significantly improve supply of $\mathrm{Ca}$ whereas it immobilized the phytotoxic micronutrient $\mathrm{Mn}$. The present result is in line with the finding of Chali [49] who reported highest exchangeable Ca result from the application of $10 \mathrm{t}$ coffee husk compost ha ${ }^{-1}$ and the lowest value from the control plot.

3.1.9. Exchangeable Magnesium $\left(\mathrm{Mg}^{2+}\right)$. The soil exchangeable magnesium also significantly $(p<0.01)$ affected by the application of the main factors of CHC and NPSB fertilizers and their interaction with (Table 5). The highest soil exchangeable magnesium (14.31 meq $\left.100 \mathrm{~g}^{-1}\right)$ was recorded from the application of $5 \mathrm{tha}^{-1} \mathrm{CHC}$ and $112.5 \mathrm{~kg} \mathrm{ha}^{-1}$ NPSB fertilizer which is statistically similar with the combined application of $7.5 \mathrm{tha}^{-1} \mathrm{CHC}$ and $112.5 \mathrm{~kg} \mathrm{ha}^{-1}$ NPSB fertilizer, while the least value exchangeable magnesium (7.62 meq $100 \mathrm{~g}^{-1}$ ) was recorded from treatment applied with highest rate of NPSB fertilizer alone which is at par with other plots applied with sole NPSB fertilizers and control (Table 5). Furthermore, the combined application of $5 \mathrm{tha}^{-1} \mathrm{CHC}$ and $112.5 \mathrm{~kg} \mathrm{ha}^{-1}$ NPSB fertilizer improved the soil exchangeable $\mathrm{Mg}^{2+}$ by $61 \%$ (from 8.89 to 14.31) while the highest rate of blended chemical fertilizer reduced the soil exchangeable $\mathrm{Mg}^{2+}$ by $14 \%$ (from 8.89 to 7.62) when compared to initial soil exchangeable $\mathrm{Mg}^{2+}$ (Tables 1 and 5).

This result might be because of increase in $\mathrm{Mg}^{2+}$ availability with increasing $\mathrm{pH}$ as a consequence of the alkalinity of applied $\mathrm{CHC}$ and the lowest exchangeable magnesium in the plots amended with sole NPSB fertilizers might be attributed with leaching of $\mathrm{Mg}^{2+}$. Duong [38] reported that compost have high CEC and have a potential to increase basic cations $\left(\mathrm{Ca}^{2+}, \mathrm{Mg}^{2+}, \mathrm{K}^{+}\right.$, and $\left.\mathrm{Na}^{+}\right)$of soils when incorporated. This result is in agreement with finding of Chali [49] and Kasongo et al. [53] who reported increase in exchangeable $\mathrm{Mg}^{2+}$ in soil with application of coffee waste to soil. 
TABLE 5: Interaction effect of CHC and NPSB fertilizer on CEC and exchangeable bases of soils of potato field.

\begin{tabular}{|c|c|c|c|c|}
\hline \multicolumn{2}{|c|}{ Treatment } & \multirow{2}{*}{ CEC (meq $100 \mathrm{~g}^{-1}$ ) } & \multirow{2}{*}{ Exch.Ca ${ }^{2+}\left(\right.$ meq $\left.100 \mathrm{~g}^{-1}\right)$} & \multirow{2}{*}{ Exch. $\mathrm{Mg}^{2+}\left(\right.$ meq $\left.100 \mathrm{~g}^{-1}\right)$} \\
\hline $\mathrm{CHC}$ & NPSB & & & \\
\hline 0 & 0 & $12.12^{\mathrm{fg}}$ & $18.57^{\mathrm{e}}$ & $7.95^{\mathrm{g}}$ \\
\hline 0 & 112.5 & $12.17^{\mathrm{fg}}$ & $18.17^{\mathrm{e}}$ & $7.94^{\mathrm{g}}$ \\
\hline 0 & 150 & $12.15^{\mathrm{fg}}$ & $18.30^{\mathrm{e}}$ & $7.91^{\mathrm{g}}$ \\
\hline 0 & 187.5 & $12.05^{\mathrm{g}}$ & $18.27^{\mathrm{e}}$ & $7.62^{\mathrm{g}}$ \\
\hline 2.5 & 0 & $12.35^{\mathrm{efg}}$ & $18.47^{\mathrm{e}}$ & $10.71^{\mathrm{e}}$ \\
\hline 2.5 & 112.5 & $12.43^{\mathrm{efg}}$ & $19.09^{\mathrm{e}}$ & $11.00^{\mathrm{e}}$ \\
\hline 2.5 & 150 & $13.27^{\mathrm{b}}$ & $20.53^{\mathrm{d}}$ & $10.14^{\mathrm{f}}$ \\
\hline 2.5 & 187.5 & $12.73^{\text {cde }}$ & $20.45^{\mathrm{d}}$ & $10.00^{\mathrm{f}}$ \\
\hline 5 & 0 & $13.10^{\mathrm{bc}}$ & $22.10^{\mathrm{bc}}$ & $11.66^{\mathrm{d}}$ \\
\hline 5 & 112.5 & $12.95^{\mathrm{bcd}}$ & $20.55^{\mathrm{d}}$ & $14.31^{\mathrm{a}}$ \\
\hline 5 & 150 & $13.08^{\mathrm{bc}}$ & $21.40^{\mathrm{cd}}$ & $12.42^{\mathrm{c}}$ \\
\hline 5 & 187.5 & $12.57^{\mathrm{def}}$ & $21.24^{\mathrm{cd}}$ & $13.36^{\mathrm{b}}$ \\
\hline 7.5 & 0 & $14.10^{\mathrm{a}}$ & $21.84^{\mathrm{bc}}$ & $13.30^{\mathrm{b}}$ \\
\hline 7.5 & 112.5 & $14.05^{\mathrm{a}}$ & $21.60^{\mathrm{bc}}$ & $14.06^{\mathrm{a}}$ \\
\hline 7.5 & 150 & $14.08^{\mathrm{a}}$ & $23.22^{\mathrm{a}}$ & $12.35^{\mathrm{c}}$ \\
\hline 7.5 & 187.5 & $13.98^{\mathrm{a}}$ & $22.47^{\mathrm{b}}$ & $11.99^{\mathrm{cd}}$ \\
\hline \multicolumn{2}{|c|}{$F$-test } & $*$ & $* *$ & $* * *$ \\
\hline \multicolumn{2}{|c|}{ LSD (0.05) } & 0.41 & 0.95 & 0.56 \\
\hline \multicolumn{2}{|c|}{$\mathrm{CV}(\%)$} & 1.91 & 2.80 & 3.06 \\
\hline
\end{tabular}

Means sharing the same letter within a column are not significantly different according to LSD at $5 \%$ level of significance; CV $=$ coefficient of variation; * $=$ significant at $p=0.05 ;{ }^{* *}=$ significant at $p=0.01 ;{ }^{* * *}=$ significant at $p=0.001 ; \mathrm{CEC}=$ cation exchange capacity; Exch.Ca ${ }^{2+}=$ exchangeable calcium; Exch. $\mathrm{Mg}^{2+}=$ exchangeable magnesium; meq = mill equivalent.

3.1.10. Exchangeable Potassium $\left(K^{+}\right)$. The soil exchangeable $\mathrm{K}$ was significantly $(p<0.01)$ affected by the application of CHC and NPSB fertilizer while did not influenced by their interaction (Table 4). The highest soil exchangeable $\mathrm{K}\left(2.12 \mathrm{meq} 100 \mathrm{~g}^{-1}\right)$ was resulted from the application of $7.5 \mathrm{tha}^{-1} \mathrm{CHC}$ alone, while the least exchangeable K result $\left(0.61 \mathrm{meq} 100 \mathrm{~g}^{-1}\right)$ was recorded from unfertilized plot. On the other hand, the highest soil exchangeable $\mathrm{K}\left(1.72 \mathrm{meq} 100 \mathrm{~g}^{-1}\right)$ was resulted from unfertilized plot with NPSB fertilizer which is statistically similar with plot supplied with $112.5 \mathrm{~kg} \mathrm{ha}^{-1}$ NPSB fertilizer alone, while the lowest exchangeable $\mathrm{K}$ result $(1.32 \mathrm{meq}$ $100 \mathrm{~g}^{-1}$ ) was recorded from application of $187.5 \mathrm{~kg} \mathrm{ha}^{-1}$ NPSB fertilizer alone (Table 4). Application of the highest rate of $\mathrm{CHC}$ tended to improve the initial soil exchangeable $\mathrm{K}^{+}$by more than $100 \%$ (from 0.61 to 2.12 ) (Tables 1 and 4 ).

The improvement in exchangeable K over the sole NPSB fertilizer and control might be related to exchangeable $\mathrm{K}$ release to soil as result of mineralization from $\mathrm{CHC}$ and also the beneficial effect of coffee waste application in its capacity to supply soil exchangeable $\mathrm{K}[13,17]$. The lowest exchangeable $\mathrm{K}$ result from application of highest rate of NPSB fertilizer alone might be attributed with leaching of $\mathrm{K}^{+}$. This finding is in agreement with the result of Chali [49] and Kasongo et al. [50] and those reported increase in soil exchangeable $\mathrm{K}$ as a result of $\mathrm{CHC}$ applied to acid soils alone and in combinations.

3.1.11. Exchangeable Sodium $\left(\mathrm{Na}^{+}\right)$. Exchangeable sodium of the experimental soil after harvest was also significantly $(p<0.0001)$ affected by the application of the main factors of $\mathrm{CHC}$ and not influenced by the application of main factors of NPSB fertilizer and its interactions with CHC (Table 4). The highest soil exchangeable $\mathrm{Na}^{+}\left(0.054\right.$ meq $\left.100 \mathrm{~g}^{-1}\right)$ was recorded from treatment applied with the $7.5 \mathrm{tha}^{-1} \mathrm{CHC}$ alone, while the lowest soil exchangeable $\mathrm{Na}^{+}(0.032 \mathrm{meq}$ $100 \mathrm{~g}^{-1}$ ) was recorded from unfertilized plots (Table 5). On the other hand, the highest rate of $\mathrm{CHC}$ improved the soil exchangeable $\mathrm{Na}^{+}$by more than $100 \%$ (from 0.02 to 0.054 ) when compared to initial soil exchangeable $\mathrm{Na}^{+}$value (Tables 1 and 4). This result might be because of released $\mathrm{Na}^{+}$ from applied $\mathrm{CHC}$ to soil and coffee waste application promoted the retention of cations [17]. Takala Dibaba et al. [52] also reported the improvement of exchangeable $\mathrm{Na}^{+}$ due to addition of compost to the soils.

\section{Conclusion}

This research was carried out with the objective of evaluating effects of different rates of coffee husk compost (CHC) and NPSB fertilizer on selected soil chemical properties of potato field during 2021 under supplemental irrigation. The result showed that combined application of CHC and NPSB fertilizer raises the soil $\mathrm{pH}$ by $24 \%$, OC by $31 \%$ and improved the total $\mathrm{N}$ by $117 \%$, improves the available $\mathrm{P}$ of the soil, reduces the exchangeable acidity, and raises the CEC and exchangeable bases of the experimental soil when compared to the control as well as the initial soil. In general, the result of current experiment indicated that combined application of CHC and NPSB blended fertilizers improves the chemical properties of the soils of potato field demonstrating the important role of combined application of organic and inorganic fertilizers in soil fertility management and thus improvement of potato crop growth and yield. Therefore, from the current findings, combined application of $5 \mathrm{tha}^{-1}$ 
CHC and $187.5 \mathrm{kgha}^{-1}$ NPSB fertilizers could be recommended for its positive impacts on soil chemical properties to improve potato production and productivity.

\section{Data Availability}

The data that support the findings of this study are available from the corresponding author upon reasonable request.

\section{Conflicts of Interest}

The authors declare that there are no conflicts of interest regarding this paper.

\section{References}

[1] FAO, The Potato Sector, Food and Agriculture Organization of the United Nations, Rome, Italy, 2019.

[2] CIAT BFS/USAID, Climate-Smart Agriculture in Ethiopia: CSA Country Profiles for Africa Series, p. 26, CIAT, Washington, D.C., USA, 2017.

[3] A. Abera and M. Belayneh, "Land use land cover dynamics as a prelude for soil resource degradation in south western part of Ethiopia, chora district in focus," International Journal of Multidisciplinary Educational Research, vol. 6, no. 4, p. 9, 2017.

[4] D. S. Douches, "Breeding and genetics for the improvement of potato (Solanum Tuberosum L.) for yield, quality and pest resistance," 2013.

[5] Central Statistical Agency, The Federal Democratic Republic of Ethiopia Central Statistical Agency Agricultural Sample Survey 2020/21. Report on Area and Production of Major Crops of Meher Season Private Peasant Holdings, Vol. I, CSA, , Addis Ababa, Ethiopia, 2021.

[6] H. Setu, N. Dechassa, and Y. Alemayehu, "Influence of phosphorus and potassium fertilizers on growth and yield of potato (Solanum tuberosum L.) at assosa, benishangul Gumuz regional state, and western Ethiopia," Journal of Soil Science and Environmental Management, vol. 9, no. 6, pp. 81-90, 2018.

[7] IFPRI, Fertilizer and Soil Fertility Potential in Ethiopia Constraints and Opportunities for Enhancing the System, International Food Policy Research Institute, Washington, D.C., USA, Working Paper, 2010.

[8] W. Haile, "Integrated soil fertility management technology for improving potato (SolanumTubersosum L.) production and soil productivity at chencha, southern Ethiopia," Journal of the Dry Lands, vol. 7, no. 2, pp. 683-696, 2017.

[9] I. Zewide, T. Tana, W. Lemma, and M. Ali, "Effect of combined use of cattle manure and inorganic nitrogen and phosphorus on yield components yield and economics of potato (Solanum tuberosum L.) in belg and meher season at abelo area masha district, south-western Ethiopia," Journal of Agricultural Science and Food Research, vol. 9, no. 1, p. 214, 2018.

[10] M. Alemayehu, M. Jemberie, T. Yeshiwas, and M. Aklile, "Integrated application of compound NPS fertilizer and farmyard manure for economical production of irrigated potato (Solanum tuberosum L.) in highlands of Ethiopia," Cogent Food \& Agriculture, vol. 6, no. 1, Article ID 1724385, 2020.

[11] V. B. Agegnehu and M. I. Bird, "Influence of integrated soil fertility management in wheat and teff productivity and soil chemical properties in the highland tropical environment,"
Journal of Soil Science and Plant Nutrition, vol. 14, pp. 532545, 2014.

[12] G. Chala and G. Gurmu, "Effect of organic and inorganic fertilizers on growth and yield of teff (Eragrostis teff) in the central highlands of Ethiopia," Ethiopian Journal of Agriculture Science, vol. 27, no. 1, pp. 77-88, 2017.

[13] B. A. Nduka, D. B. Adewale, O. S. O. Akanbi, and K. B. Adejobi, "Nursery soil amendments for cashew seedling production. A comparative analysis of coffee husk and NPK," Journal of Agricultural Science, vol. 7, no. 3, pp. 111-122, 2015.

[14] A. Kivaisi and B. Assefa, Sustainable Utilization of Agro-Industrial Wastes through Integration of Bio-Energy and Mushroom Production, ILRI, Nairobi, Kenya, 2010.

[15] A. G. Woldesenbet, B. Woldeyes, and B. S. Chandravanshi, "Bio-ethanol production from wet coffee processing waste in Ethiopia," SpringerPlus, vol. 5, no. 1, p. 1903, 2016.

[16] S. Nayak and M. J. Harshitha, "Isolation and characterization of caffeine degrading bacteria from coffee pulp," Indian Journal of Biotechnology, vol. 11, pp. 86-91, 2012.

[17] R. K. Kasongo, G. B. Verdoodt, E. Van Ranst, P. Kanyankagote, G. Baert, and E. V. Ranst, "Coffee waste as an alternative fertilizer with soil improving properties for sandy soils in humid tropical environments," Soil Use and Management, vol. 27, no. 1, pp. 94-102, 2011.

[18] N. Anh Dzung, T. Trung Dzung, and V. Thi Phuong Khanh, "Evaluation of coffee husk compost for improving soil fertility and sustainable coffee production in rural central highland of vietnam," Resources and Environment, vol. 3, no. 4, pp. 77-82, 2013.

[19] D. B. Sekhar, P. B. Pradeep Kumar, and K. Tejeswara Rao, "Effect of coffee husk compost on growth and yield of paddy," Journal of Academia and Industrial Research, vol. 3, no. 4, pp. 195-197, 2014.

[20] A. Regassa, "Characterization of agricultural soils in capacity building for scaling up of evidence based best practices in agricultural production in ethiopia intervention woredas in western oromia region: final report," 2015.

[21] CANRO (Chora District Agriculture and Natural Resource Office), "Chora district agriculture and natural resource: office data," 2019.

[22] T. Tadese, Soil, Plant, Water, Fertilizer, Animal Manure And Compost Analysis, International Livestock Research Center for Africa, Addis Ababa, Ethiopia, Working Document No. 13, 1991.

[23] H. F. Murphy, A Report on Fertility Status and Other Data on Some Soils of Ethiopia, Experimental Station Bulletin No. 44, p. 551, Collage of Agriculture HSIU, Dire Dawa, Ethiopia, Collage of Agriculture HSIU, 1968.

[24] S. R. Olsen, C. V. Cole, F. S. Watanabe, and L. A. Dean, Estimation of Available Phosphorus in Soils by Extraction with Sodium Bicarbonate, U. S. Department of Agriculture Circular No. 939, Washington, D.C., USA, 1954.

[25] P. Hazelton and B. Murphy, Interpreting Soil Test Results: What Do All the Numbers Mean?p. 152, 2nd edition, CSIRO Publishing, Clayton, Australia, 2007.

[26] FAO (Food and Agriculture Organization), Plant Nutrition for Food Security: A Guide for Integrated Nutrient Management, Vol. 16, FAO, Fertilizer and Plant Nutrition Bulletin, , Rome, Italy, 2006.

[27] S. Asredie, W. De Jong, K. Perry, H. Donald, and F. Mengistu, "Participatory variety selection: a tool to understand farmers potato variety selection criteria," Open Agriculture, vol. 2, pp. 453-463, 2017. 
[28] ATA, ATA Developed Soil Fertility Status and Fertilizer Recommendation Map Report, ATA, Addis Ababa, Ethiopia, 2019.

[29] EIAR, Crop Technologies Guideline, Ethiopian Institute of Agricultural Research, Addis Ababa, Ethiopia, 2007.

[30] S. H. Chopra and J. S. Kanwar, Analytical Agricultural Chemistry, Kalyani Publisher, New Delhi, India, 1976.

[31] A. Walkley and I. A. Black, "An examination of the degtjareff method for determining soil organic matter, and a proposed modification of the chromic acid titration method," Soil Science, vol. 37, no. 1, pp. 29-38, 1934.

[32] Bremner and C. S. Mulvaney, A. L. Page, R. H. Miller, and D. R. Keeney, Nitrogen-total in Methods of Soil Analysis, Part 2, Chemical and Microbiological Propertiespp. 595-624, American Society of Agronomy, Madison, WI, USA, 2nd edition, 1982.

[33] P. R. Warman and H. G. Sampson, "Evaluation of soil sulfate extractants and methods of analysis for plant available sulfur," Communications in Soil Science and Plant Analysis, vol. 23, no. 7-8, pp. 793-803, 1992.

[34] D. L. Rowell, Method and Applications, Addison Wesley Longman Limited, London, UK, 1994.

[35] H. D. Chapman, "Cation exchange capacity in C.A. Black," Methods of Soil Analysis-Chemical and Microbiological Properties: Agronomy, vol. 9, pp. 891-901, 1965.

[36] G. J. Bouyoucos, "A recalibration of the hydrometer method for making mechanical analysis of soils 1," Agronomy Journal, vol. 43, no. 9, pp. 434-438, 1951.

[37] V. C. Jamison, H. A. Weaver, and I. F. Reed, "A hammerdriven soil-core sampler," Soil Science, vol. 69, no. 6, pp. 487-496, 1950.

[38] C. Pisa and W. Menas, "Evaluation of composting performance of mixtures of chicken blood and maize stover in harare, Zimbabwe," International Journal of Recycling of Organic, vol. 2, no. 1, pp. 1-11, 2013.

[39] P. M. Ndegwa and S. A. Thompson, "Integrating composting and vermicomposting in the treatment and bioconversion of biosolids," Bioresource Technology, vol. 76, no. 2, pp. 107-112, 2001.

[40] J. R. Okalebo, K. W. Guthua, and P. J. Woomer, Laboratory Methods of Soil and Plant Analysis a Working Manual, TSBFCIAT and SACRED Africa, Nairobi, Kenya, 2002.

[41] T. T. T. Doung, Compost effect on soil properties and plant growth, PhD. Thesis, University of Adelaide, Adelaide, Australia, 2013.

[42] A. Islam and M. F. Alma, "Integrated nutrient management for potato (Solanum tuberosum) in grey terrace soil," Australian Journal of Crop Science, vol. 7, no. 9, pp. 1235-1241, 2013.

[43] N. K. Fageria, The Use of Nutrients in Crop Plants, CRC Press: Taylor and Francis Group, Boca Raton, FL, USA, 2009.

[44] N. Brady and R. Weil, The Nature and Properties of Soils, Pearson Education, Columbus, OH, USA, 2016.

[45] Z. Rengel, "Soil pH, soil health and climate change, soil biology," in Soil Health and Climate Change, pp. 69-85, Springer, Berlin, Germany, 2011.

[46] G. Adugna, "A review on impact of compost on soil properties, water use and crop productivity," Academic Research Journal of Agricultural Science and Research, vol. 4, no. 3, pp. 93-104, 2016.

[47] E. Afriyie and B. Amoabeng, "Effect of compost amendment on plant growth and yield of radish (Raphanus sativus L.)," Journal of Experimental Agriculture International, vol. 15, no. 2, pp. 1-6, 2017.
[48] M. Mekashaw, M. Alemayehu, G. Shumye, and A. Haileslassie, "Effects of blended NPS fertilizer rates on yield and yield components of potato (solanum tuberosum L.) varieties at dessie zuria district, northeast Ethiopia," Food and Agriculture, vol. 6, no. 1, 2020.

[49] G. Chali, "Effect of integrated use of coffee husk compost and NPS fertilizer on soil physicochemical properties, growth and yield of coffee (Coffea Arabica L.)," Agriculture, Forestry and Fisheries, vol. 10, no. 6, pp. 233-244, 2020.

[50] F. Solomon, A. Asrat, D. Tadesse, Z. G. Medhin, and E. Agegnehu, "Evaluation of potato (Solanum tuberosum L.) varieties for yield and yield components," Journal of Horticulture and Forestry, vol. 11, no. 3, pp. 48-53, 2018.

[51] B. Takala, "Soil acidity and its management options in western Ethiopia: review," Journal of Environment and Earth Science, vol. 9, no. 10, pp. 2224-3216, 2019.

[52] B. Takala Dibaba, T. Kufa, and A. Regassa, "Effects of lime and coffee husk compost on growth of coffee seedlings on acidic soil of haru in western Ethiopia," Journal of Degraded and Mining Lands Management, vol. 8, no. 1, pp. 2391-2400, 2020.

[53] R. K. Kasongo, A. Verdoodt, P. Kanyankogote, G. Baert, and E. Van Ranst, "Response of Italian ryegrass (Lolium multiflorumLam.) to coffee waste application on a humid tropical sandy soil," Soil Use and Management, vol. 29, no. 1, pp. 22-29, 2013. 